\title{
Inquiring Into the Assessment Education of Preservice Teachers: A Collaborative Self-Study of Teacher Educators
}

\author{
Elizabeth Ann Munroe, Jennifer Mitton-Kükner, and Deborah Graham \\ St. Francis Xavier University
}

\begin{abstract}
As professors teaching courses in classroom assessment in a Bachelor of Education program, we engage in collaborative self-study as a means to understand the complexity of our preservice teachers' learning. Here we describe two of the strategies we use in our teaching: purposefully introducing competing philosophies early in our courses, and guiding our preservice teachers' to inquire deeply into their assessment histories. We examine our preservice teachers' differing responses, which range from misunderstanding or resisting to thinking deeply about the course content. We conclude by identifying three protective factors that support us as we work with preservice teachers in the area of assessment education.
\end{abstract}

Keywords: assessment education; preservice teacher education; self-study

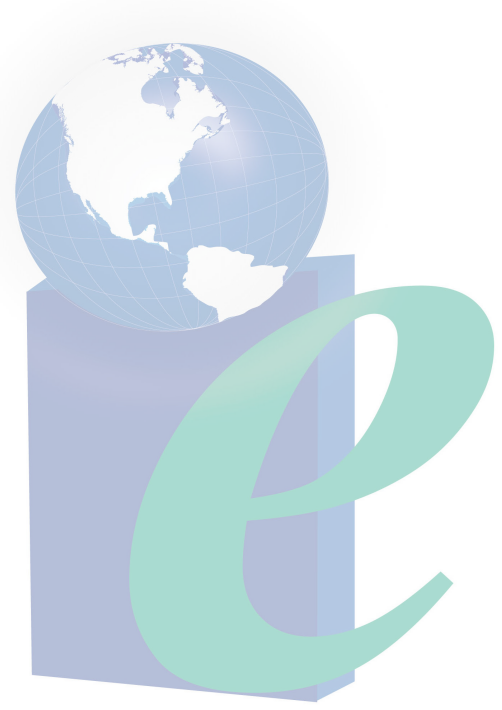




\title{
Inquiring Into the Assessment Education of Preservice Teachers: A Collaborative Self-Study of Teacher Educators
}

\author{
Assessment is essential for teachers and students to inform the process of \\ learning. It tells teachers how their students are learning and students if \\ they are on the right track. If done right, assessment is, essentially, what \\ leads to student success (University preservice teacher, essay, 2013)
}

This quote is taken from a short essay ${ }^{1}$ written by a university preservice teacher ${ }^{2}$ upon the completion of a course in Classroom Assessment and Evaluation, in the first term of her second year in a two-year Bachelor of Education (B.Ed.) degree. Instead of conceptualizing assessment as a way to measure student success in learning provincial achievement outcomes, this preservice teacher demonstrated a deep understanding of the way that assessment may contribute to that student success. As teacher educators, we aim to foster a level of understanding about classroom assessment that is illustrated in the opening quote. We realize, however, that this conceptual sophistication is not representative of all the preservice teachers who take our courses; some misunderstand this idea, and still others reject this concept. To pass our course, preservice teachers must demonstrate their understanding of current classroom assessment philosophy and strategies. Our influence, however, does not necessarily change all of their beliefs. Our process is similar to classroom teachers who are guided by a Success for All (SFA) philosophy (Stiggins, 2005). We use supportive, ongoing classroom assessment practices with the goal of leading each of our preservice teachers to be as successful as possible, but at the end of our courses, we are required to make professional judgments on the degree of understanding they have achieved. We use assessment practices to both contribute to student success and to measure student success.

For the past several years, we have been involved in a collaborative self-study of our teaching of assessment and evaluation courses to preservice teachers (Munroe et al., 2012). Explicit modeling of assessment practices during preservice teacher education is a process recommended by many researchers (Graham, 2005; Lunnenberg, Korthagen, \& Swennen, 2007; Roscoe, 2013; Volante, 2006b; Volante \& Fazio, 2007). Thus, the design of our courses and our teaching practices are informed by explicit modeling of assessment for, as, and of learning purposes (Black \& Wiliam, 1998; Earl, 2013). We have also examined the tensions and challenges of perspectives surrounding grades when working with preservice teachers, as we help them to experience assessment aimed at promoting what Stiggins (2005) terms "Success For All,"3 while they and we work in a university environment based on a traditional sort and rank (Stiggins, 2005) philosophy (Mitton-Kukner, Munroe, \& Graham, in press). In our teaching, we systematically provide opportunities for our students to experience current assessment practices with the hope that they will use them in their future teaching. Beyond that, however, we expect our students to formulate wise beliefs about the importance, indeed the urgency, of assessment based on a SFA philosophy. We want our graduates to consider all assessment decisions from a stance of equity and to be able to mitigate persistent remnants of the sort and rank practices still evident in public schools. Table 1, below, illustrates the classroom assessment practices reflecting a SFA philosophy in contrast with traditional classroom assessment practices based on a sort and rank philosophy. 
Earl (2013) describes a major philosophical shift in beliefs and practices in classroom assessment, from acceptance of student failure to a dedication to work towards SFA students. As educators, we note that although a philosophy of supporting the success of all students is increasingly evident in the K-12 school sector, many aspects of the school system continue to reflect a philosophy predicated on sorting students in both obvious and subtle ways. Our province has lists of curriculum outcomes and teachers must make summative evaluations regarding the degree to which students have achieved those outcomes. Achieving a thorough understanding of the outcomes might be defined as the highest possible student success. Do all students attain this level? No. Are some students deemed to have only limited understanding of the outcomes? Unfortunately, yes. For us, the question is, what have the teachers done for all students to work towards the highest success possible? The shift in classroom assessment practices lies in the extent to which teachers support all students in a myriad of ways (such as those listed in the left hand column of Table 1), rather than using traditional strategies which are based on the philosophy that student failure is an acceptable option (such as those in the right hand column of Table 1). We hope our preservice teachers will develop a belief in the effectiveness of helping students to be successful throughout the learning process (Black \& Wiliam, 1998), so that students achieve a higher degree of success when final evaluative judgments are made (at report card time).

Table 1

Success for All Classroom Assessment Practices Contrasted With Sort and Rank Traditional Classroom Assessment Practices

\begin{tabular}{|l|l|}
\hline \multicolumn{1}{|c|}{$\begin{array}{c}\text { Strategies Based on a Success for All } \\
\text { Philosophy }\end{array}$} & \multicolumn{1}{c|}{$\begin{array}{c}\text { Strategies Based on a Sort and Rank } \\
\text { Philosophy }\end{array}$} \\
\hline $\begin{array}{l}\text { Descriptive feedback with opportunities } \\
\text { to improve assignments }\end{array}$ & All assignments marked summatively \\
\hline $\begin{array}{l}\text { Clear criteria for assignments, given in } \\
\text { advance to students, and closely adhered } \\
\text { to as assignments are marked }\end{array}$ & $\begin{array}{l}\text { Vague or lack of clear expectations for } \\
\text { assignment completion }\end{array}$ \\
\hline $\begin{array}{l}\text { Opportunities for self assessment and } \\
\text { peer assessment with reference to course } \\
\text { outcomes presented in student-friendly } \\
\text { language and to clear assignment criteria }\end{array}$ & $\begin{array}{l}\text { Little opportunity for feedback during } \\
\text { assignment work }\end{array}$ \\
\hline $\begin{array}{l}\text { Opportunities to co-construct criteria for } \\
\text { assignments with the intent of helping } \\
\text { students be very clear on expectations }\end{array}$ & No input into expectations for assignments \\
\hline $\begin{array}{l}\text { Marks for assignments directly reflecting } \\
\text { student knowledge and skill in relation to } \\
\text { course outcomes }\end{array}$ & $\begin{array}{l}\text { Marks for assignments skewed by aspects } \\
\text { of student behaviour or work habits (such } \\
\text { as late submissions) }\end{array}$ \\
\hline $\begin{array}{l}\text { Opportunities to demonstrate skill and } \\
\text { knowledge through a variety of formats } \\
\text { (including visual, oral, and written) }\end{array}$ & $\begin{array}{l}\text { Over-reliance on testing and no choice in } \\
\text { format to demonstrate skill and knowledge }\end{array}$ \\
\hline
\end{tabular}


As faculty members who have taught classroom assessment and evaluation courses in our university's Faculty of Education several times over the past five years, we work together as a learning community and we systematically study our teaching practice. When we concluded a phase of our self-study last year, based on our review of the literature and our analysis of our preservice teachers' learning, we proposed two actions for the next time we taught the assessment and evaluation courses (MittonKukner et al., in press). We vowed to:

1. Explicitly describe a SFA philosophy and distinguish it from sort and rank (Stiggins 1999, 2005) in our courses.

2. Create opportunities for students to inquire into their assessment experiences using the two philosophies of SFA and sort and rank as part of their theoretical lens, to interrogate their own assessment histories (Graham, 2005; Wang, Kao, \& Lin, 2010).

In what follows, we report on our progress regarding the two aforementioned strategies implemented in our 2013 assessment courses, offering examples of preservice teachers' responses to contemporary assessment practices. As teacher educators, we require our preservice teachers to think deeply about ideas represented by a major philosophical shift regarding classroom assessment (Earl, 2013). Each year, through our collaborative selfstudy, we understand a little more about the complexity that this shift presents to our preservice teachers.

\section{Our Context}

The B.Ed. program at our small rural Canadian university is completed over two academic years. Our university students, whom we refer to as preservice teachers, have previously completed a bachelor's degree with course specifications approved by the provincial Department of Education and Early Childhood Development. We have approximately 115 preservice teachers in each year of our program. Every preservice teacher is required to take a three-credit (one semester; 36 hours) course in classroom assessment and evaluation in the first semester of their second year of study. There are three sections of the course, and approximately 40 preservice teachers are enrolled in each course.

We have observed that when preservice teachers begin their classroom assessment and evaluation course, they are anxious to learn more about this topic. At this point, they have already been in schools for 11 weeks to fulfill their program field experience requirements. During their field experience, they have observed a wide variety of assessment practices implemented by their cooperating teachers; they have taught, and therefore, considered the degree to which their students have learned. They arrive in our classrooms with many questions about all aspects of the classroom assessment and evaluation process. We find the course is often challenging for our preservice teachers and that we may encounter some resistance to the ideas we present. As the semester unfolds, we meet regularly as a self-study group to offer collegial support, but primarily to continue our own learning journey. To situate our study, we turn to recent literature on the topic of classroom assessment and teaching preservice teachers about classroom assessment. 


\section{Current Ideas and Practices Regarding Classroom Assessment}

Classroom assessment is commonly understood as having multiple purposes with teachers playing a critical role in its purposeful usage (Earl, 2013; McMillan, Hellsten, \& Klinger, 2011). In response to the growing understanding of classroom assessment as integral to a teachers' instructional practices and student learning (Black \& Wiliam, 1998; Shepard et al., 2005), teachers are expected to be knowledgeable of and comfortable with the application of diagnostic, formative, and summative purposes of assessment (Earl, 2013; Popham, 2011). Assessments are understood to provide teachers with ongoing knowledge of student learning and progress, helping them to make instructional decisions that will positively impact student learning and achievement (Black \& Wiliam, 1998; Wiliam, Lee, Harrison, \& Black, 2004), while also providing students with feedback and guidance on their learning (Chappuis, 2009). The assessment education of teachers continues to be an ongoing focus in research and educational policies (Klinger, Volante, \& Deluca, 2012; Popham, 2009). Underlying this body of work is the fundamental idea that classroom assessment can be informative for both teachers and students in that it is aligned with teachers' decision-making, instructional practices, and learning activities, and with students' progress. For example, in this conceptualization of teaching and learning, students should be aware of curriculum outcomes, the criteria of sound performance for particular assessment tasks, and the progress they are making towards the achievement of specific outcomes as provided in the form of teacher feedback and self-assessment/monitoring.

In Canada, school boards and provinces have responded to the developments in understandings about classroom assessment. School boards and provincial ministries across the nation have addressed the importance of teachers' classroom assessment practices and their connections to student learning and achievement (Alberta Assessment Consortium, 2012; Kids \& Learning First, 2012; Manitoba Education, Citizenship \& Youth, 2006). Studies have shown that teachers are becoming more acquainted with different kinds of assessment practices (Gunn \& Hollingsworth, 2013; Volante \& Beckett, 2011; Wilson, 2008), although there is a tendency to depend on summative assessment methods (Duncan \& Noonan, 2007; Remasal, 2011; Smith, 2011; Stiggins, 2002; Volante, 2010). At the same time, changes in understanding about the importance of classroom assessment and the role of teachers in student learning have occurred in an era of increasing standardized, large-scale assessment in Canada (Duncan \& Noonan, 2007; Erickcan \& Barclay-McKeown, 2007; Klinger, Deluca, \& Miller, 2008; Volante \& Fazio, 2007; Volante, 2006a). Canadian scholars note that because classroom assessment is complex, it is anything but tension-free, as its purposes potentially compete and conflict (Earl, 2013; Volante \& Beckett, 2011; Volante, 2010).

\section{Teaching Preservice Teachers About Classroom Assessment}

In this current educational context, preservice teachers enter into the field and are expected to be able to understand and apply a variety of classroom assessments that respond to and document student learning (Goc Karp \& Woods, 2008; Roscoe, 2013). Yet, for many preservice teachers, the multipurpose nature of classroom assessment goes against what they have experienced as students in schools (Lortie, 2002) and in higher education settings (Koedel, 2011; Rojstaczer \& Healy, 2010; Roscoe, 2013). Research 
has shown that preservice teachers are largely uninformed about classroom assessment and its relationship with instructional practices and student learning (Campbell \& Evans; 2000; Graham, 2005; Roscoe, 2013; Volante \& Fazio, 2007; Wang, et al., 2010).

Scholars suggest that in order to educate about assessment, explicit modeling of contemporary instructional and assessment strategies by teacher educators is needed (Graham, 2005; Roscoe, 2013; Volante, 2006b; Volante \& Fazio, 2007). These educative experiences allow them to experience the different purposes of classroom assessment as learners (Poth, 2013; Volante, 2006b; Wang et al., 2010). The above literature review illustrates the complexity of navigating the major philosophical shift in beliefs and practices in classroom assessment (Earl, 2013), and provides some insights into our experiences teaching preservice teachers about classroom assessment.

\section{Methodology and Methods}

This examination of our teaching practice is anchored in self-study methodology, as recommended by Zeichner (1995). Self-study "supports researchers in understanding their work, [and] questioning the possibilities of practice” (Hamilton \& Pinnegar, 2013, p. 75), and has been credited with improving instruction (Lunenberg, Korthagen, \& Swennen, 2007). As colleagues from varying backgrounds and leadership in assessment and evaluation in schools, from two provinces in Canada, and from two international settings (Turkey and Malaysia), we bring to this topic and our self-study unique and shared conceptions and experiences. We concur with Loughran (2006) that "new understandings may emerge as situations become better clarified and questioned” (p. 49) through a collaborative, investigative process.

Applying methods borrowed from other "more established forms of research," self-study research has been termed "a mongrel” (Bullough \& Pinnegar, 2001, p. 15). To counter this perception, researchers are encouraged to provide details about data sources, collection, and analysis so that the reader may judge the legitimacy of the research. Our process has been to meet on a regular basis to discuss and ponder over the assessmentrelated conversations that occur during our classes. The analysis of the data sources inductively unfolds as we meet together to consider and reconsider what is important in our teaching experiences, what the preservice teachers are demonstrating to us, and what this means in terms of next steps in our teaching. Are there trends? Are their outliers? Are preservice teachers responding differently this year in comparison to past years of teaching the Classroom Assessment and Evaluation courses? How much of a shift in philosophy is reasonable to expect in our students during the compact 9-week courses? With these questions in mind, we share our individual reflective field notes and anonymous examples of preservice teachers' comments and questions and samples of written responses to class activities and assignments. We cluster the responses, as our intention is not to consider any individual student as a research participant. Rather we look upon the whole as a reflection of our teaching and we depend on that whole to help us understand our classroom practices.

\section{Early and Continuous Emphasis on a Success for All Philosophy}

One goal for us this past year was to more explicitly describe SFA philosophy and distinguish it from sort and rank (Stiggins 1999, 2005) at the beginning of our courses. 
This approach reflects our recognition of the complexity of these competing philosophies and our hope that early and repeated reference to the philosophies would enhance the learning of our preservice teachers. To this end, we set up an activity usually referred to as the Clapping Exercise (Davies, 2004) wherein the preservice teachers watch a series of performances and evaluations acted out by their peers, demonstrating a sequence of increased support on the part of the judges, such that the final performer is able to be far more successful than the first. This year, as the class discussed the Clapping Exercise, Elizabeth intentionally introduced SFA and sort and rank as philosophies that may underlie teachers' assessment and evaluation decisions. She explained that the unsupportive judging techniques applied to the first two performances reflect a sort and rank philosophy of assessment and evaluation, wherein failure was an acceptable option, whereas the supportive judging techniques applied to the third and fourth performances (sharing success criteria, providing descriptive feedback, offering an opportunity for a second chance) reflected a SFA philosophy of assessment and evaluation.

One preservice teacher, thinking about some of the young students she had worked with the previous year during her field experience, wondered how to assess and evaluate growth and progress, and how to give recognition for trying something while still emphasizing success in achieving an outcome. She displayed empathy, realizing that while some students may not easily demonstrate success in achieving an outcome, they might demonstrate success in of terms effort. She recognized that using supportive assessment strategies would be important, but these would not magically erase some students' struggles to learn, and she asked how teachers reported on progress, if not achievement. Elizabeth assured her class of preservice teachers that we would take up that topic in some depth as the course progressed and noted the complexity inherent in living out these philosophies (Elizabeth, field notes, September 9, 2013).

On the first day of the classroom assessment for secondary learners' course, Jennifer introduced the competing philosophies of SFA and sort and rank to her class. In response, a preservice teacher commented that during her field experience she felt she observed her cooperating teacher living out SFA philosophy with her French immersion students and a sort and rank philosophy with her core French students. The preservice teacher felt the French immersion students had more opportunities to experience SFA because her cooperating teacher demonstrated more patience for the French immersion students and their attempts to learn content through French (Jennifer, field notes, September 9, 2013). The preservice teacher expressed her concern that both philosophies could exist in a teacher's practices depending upon the situation and the teacher's perception of the students she/he teaches. It was evident that this student did not yet understand the concepts as philosophies underpinning assessment, but more as strategies a teacher might or might not choose to use. (Of course, we recognize that the philosophy is enacted through strategies, so this distinction is complex).

Thus, on the very first day of class, our discussion began to swirl around issues of the multi-faceted purposes of classroom assessment, terminology, provincially mandated curriculum, grading and reporting policies, and equity. Big ideas were being considered alongside specific strategies. In our self-study meeting following these initial classes, we agreed that it was promising to have started off the course as intended with an introduction to the philosophies of SFA and sort and rank, but it was clear that we would 
have to maintain this focus throughout the course if we expected our preservice teachers to gain a deep understanding of the competing philosophies of assessment.

\section{Interrogating Assessment Histories Over the Duration of the Assessment Courses}

Our second specific goal in teaching the assessment courses in 2013 was to create opportunities for our preservice teachers to inquire into their assessment histories using the two philosophies of SFA and sort and rank as part of their theoretical lens (Graham, 2005; Wang, et al, 2010). As part of a series of activities over the 9-week course, preservice teachers were asked to think about their prior assessment experiences as learners and as teachers during their first year field experiences. For example, early in Week 2 of the course, preservice teachers were asked to develop a timeline of their assessment experiences and in Week 3, they were asked to bring in an artifact representing one of those experiences. In following weeks, they returned to these items to consider and reflect upon them in light of new content. This series of activities led to a final paper in Week 7 in which preservice teachers were asked to narrow their focus, choosing one pivotal assessment experience and interrogating it using Schwab's (1983) curriculum commonplaces of teacher, learner, subject matter(s), and milieu as a way to better understand its significance and its connection to their future teaching practices.

Some of our preservice teachers recalled positive examples as part of the range of experiences depicted in their timelines, choice of artifacts, and final papers. They described "light bulb moments," when they were able to link their long-term respect for a certain teacher to how that teacher had been so supportive and flexible in classroom assessment practices. We were surprised, however, by the frequency with which assessment and evaluation was mentioned in a negative light. Many examples showed that our preservice teachers had experienced strategies reflective of a sort and rank philosophy, such as marks deducted for each day an assignment was late, lack of clarity on assignment marking criteria, or obvious discrepancy in marks linked to gender or student popularity. It seemed that providing this group of preservice teachers with the opportunity to inquire into their prior experiences in an ongoing manner allowed them to identify the ways their assessment histories informed their teacher identities and, for some, to identify how to disrupt assessment practices they previously understood as legitimate.

\section{Preservice Teachers Misunderstanding, Rejecting, and Thinking Deeply About Success for All}

Our preservice teachers demonstrated a range of responses to the SFA philosophy emphasized in our assessment courses through class activities, discussions, and assignments as well as through our own explicit modeling of success-oriented assessment and evaluation practices. We have come to understand preservice teachers' responses as generally falling into two categories: misunderstanding or rejecting SFA and thinking hard about SFA. In what follows we share a sample of preservice teachers' responses, brought together according to the described categories. These examples are reflective of common response patterns we have observed. 


\section{Category 1: Misunderstanding and/or Rejecting Success for All}

Some of our preservice teachers' assignments seemed to demonstrate confusion or misunderstanding of the SFA philosophy. Comments such as, "Something that I need to work on as a future educator is balancing between Success for All and sort and rank" or "There are a number of strategies and that's why it is important for a teacher to understand them so they can use the best type of strategy for each student or each class" seem to point to the preservice teachers focusing on strategies to use and not making decisions based on a firmly held belief, philosophy, or particular purpose that every student should be given every opportunity to achieve success.

In other conversations with preservice teachers, comments such as "We need to push students to learn to their full potential and if we allow students to be successful all the time then they will not learn to their full capability" seemed to be a rejection of the ideas we were presenting. Or perhaps, we thought, this resistance indicated a misunderstanding of the way in which assessment strategies reflecting a SFA philosophy unfold.

Some of our preservice teachers seemed to reject the success-oriented strategies we were modeling. Jennifer wrote,

At the end of class, I described to the students why they were handing in a small piece of the unit plan on Wednesday. I explained that I wanted to see their understanding of planning instruction and assessment of learning tasks early on in the project so that I could provide them descriptive feedback upon their efforts as well as judge their learning. I asked the class if I was putting a grade on their work; some of the students, said "no" but they seemed uncertain why I was not. I emphasized that I was providing frequent opportunities for them to receive feedback on their learning so that when the time came to hand in their unit plan in Week 9, they would have a solid product, and more importantly a sound understanding of how to plan instruction and assessment when they go into the field. Some of the students said they felt passing in stages of the assignment created extra work for them. (Jennifer, field notes, September 17, 2013)

In this moment, some of the students in this class felt the instructor was asking too much of them by breaking up the assignment into smaller stages and felt they should be rewarded with a grade for their ongoing efforts. Delaying grades and providing timely, descriptive feedback is a practice we regularly employ in the teaching of the assessment courses and has a two-fold intent: to provide opportunities for preservice teachers to deepen their learning and to show the depth of their learning over time, and to model for preservice teachers how they might structure similar learning opportunities in their classrooms. However, we note that our efforts often bump into the expectations and assumptions of some preservice teachers.

The first category of preservice teachers' responses is indicative of their 18-year apprenticeship in schools (Lortie, 2002) and has provided us with new insights into preservice teachers' confusion about contemporary assessment practices as well as their resistance to our use of such practices. We noted several commonalities across their misunderstanding and resistance, particularly around seeing SFA and sort and rank 
philosophies as strategy based. We also saw the emphasis that preservice teachers placed upon products as more important signifiers of their learning rather than the processes underlying them. Perhaps most troubling was the comment by a preservice teacher who expressed concern over the idea that experiencing success all the time means students will not be motivated to learn, even though we had discussed Stiggins (2007) suggestion that low marks or rigid timelines do not cause students to work harder, but rather lead students to "give up in hopelessness" (n.p.). Overall, our preservice teachers' responses indicated to us the deep-seated nature of their prior assessment experiences and confirmed for us the necessity of an assignment that leads preservice teachers to interrogate their assessment histories. The resistance from some of our preservice teachers was mostly subtle, evident in the way they were skeptical about the assessment strategies we were using and advocating. Our self-study group helped to provide us with the resilience to persevere with helping our preservice teachers to grasp more fully the philosophy and purpose underlying current classroom assessment practices.

\section{Category 2: Thinking Hard About Success for All}

In her inquiry of an assessment experience for her final paper, one student explained that she had a high school teacher who recognized that students learn in different ways and that students deserve to express their knowledge in a way that works for them, and so the teacher allowed students to do different kinds of projects. The preservice teacher wrote,

She cared about the success for every student in the class and wanted everyone to succeed. If she had not cared, she would have had us all do the same project and have it be that whoever is good at it is in luck and whoever is not good at it is out of luck. (final paper)

To us, this preservice teacher's commentary indicated considerable understanding of the competing philosophies of SFA and sort and rank. She saw that her teacher's actions had been positioned towards student success.

Some of our preservice teachers inquired into the ways they worked with classroom assessment in their first year field experiences. Unsurprisingly, past assessment histories have a strong influence on the preservice teachers' approach to assessment during their first year of field experiences ( 5 weeks in the fall and 6 weeks in the winter). The following excerpt demonstrates a preservice teacher inquiring into the decisions she made about the development of a test.

During my first practicum, in Year 1 of the program, I created a test. I referred to the test as a 'Fiesta,' and told my Grade 10s that it was a celebration of their learning. Nearly all of them moaned and groaned over the change of test name, because it was a test all the same. The part that stuck out the most was the true/false section of my test. I created every sentence so that the only answer was false. As the test progressed, many of the students began to look around at their peers. Because of the true/false section, many of my students were confused when they kept answering false and second-guessed their answers. They raised their hands to see if they were doing something wrong. I then instructed them to read the question 
and not to second-guess their answer. I justified it by saying, to myself, that if they knew the material they would not have to second-guess themselves. The students and I had a discussion about the test the following day. One student...said that they were so confused...the true/false [section] made them change answers because they thought there was no way that all the answers could be the same. I told myself never again.... During my first practicum, I often [used] assessment methods that my teachers [used] when I was in high school. I wanted to mirror their assessment so that I could pretend to know what I was doing. (Preservice teacher, paper, October 30, 2013)

This particular moment shows a preservice teacher thinking deeply about a questionable assessment practice. She acknowledged that part of her decision to design the test in that way was based upon her previous assessment experiences as a learner in high school and her wanting to appear knowledgeable to the students, and possibly to her cooperating teacher. This particular moment was not uncommon or unusual. In our experiences of teaching preservice teachers about assessment, we often hear about preservice teachers assessing in the same manner as they were assessed as learners in schools.

The second category is reflective of those preservice teachers who inquired deeply into their understanding of assessment and its role in their classrooms. All of our preservice teachers were required to interrogate their previous assessment experiences. The examples we shared are representative of this group of individuals and demonstrated preservice teachers seriously contemplating prior experiences and actions during a previous field experience.

Although we have made two categories of preservice teachers' responses as a means of organization in this paper, in reality there was a continuum between misunderstanding or resisting the competing philosophies and demonstrating deep understanding of current assessment purposes. As in all classes of students, we saw differences in ability to think critically and a range in the degree to which our preservice teachers were able to move beyond their long apprenticeship with a sort and rank assessment philosophy.

\section{Collaboration as Fundamental to Teaching Contemporary Assessment Practices}

When our preservice teachers begin their classroom assessment and evaluation courses in the fall of their second year, they are anxious to learn more about this topic. Although principles of assessment are infused into their first year courses, we have observed that preservice teachers definitely feel the need for a dedicated course in classroom assessment in their second year. These preservice teachers are motivated to learn, yet we observe that the ideas of our classroom assessment course are challenging for them to embrace. We empathize with our preservice teachers, knowing that traditional assessment practices have pervaded their experiences as students. When we visit schools during field experience, we see that this philosophy persists in many ways in the public school system. We realize that developing a deep understanding of a SFA philosophy takes time.

Our self-study has raised our awareness of how fundamental collaboration is to our work as teacher educators. Indeed, we suggest that collaboration is a prerequisite to 
the recommendation of explicit modeling of current assessment practices by teacher educators, (Graham, 2005; Lunnenberg et al., 2007; Roscoe, 2013; Volante, 2006b; Volante \& Fazio, 2007). While we agree that explicit modeling is essential in a course about classroom assessment and evaluation, we also realize that we need to be able to "bounce back" (Gu \& Day, 2007, p. 1303) when our preservice teachers demonstrate confusion or resistance. We have determined three protective factors (Beltman, Mansfield, \& Price., 2011) that give us strength and help us to persist in our work: a) collegial team support, b) strong conviction in the effectiveness of contemporary assessment and evaluation practices, and c) success in helping many of our graduates enter the profession well versed in a SFA philosophy of assessment.

As we prepare to teach our courses on classroom assessment and evaluation, we recognize that we are entering into situations wherein the course content is challenging for our preservice teachers to learn. Working on a team of like-minded teacher educators who understand the importance and value of educating preservice teachers about competing assessment philosophies (i.e. SFA and sort and rank) and their impact upon teaching practices, enables us to persist. Meeting regularly throughout the semester to plan course activities, to debrief preservice teachers' responses, and to discuss our marking contributes to our abilities to be adaptive, reflective, open-minded, and organized. We bolster each other's spirits to maintain an optimistic and positive attitude and to keep a sense of humour. In addition to the protective power of our team support, we understand our firm commitment to empirical studies that have established the positive impact formative assessment has upon student learning (Black \& Wiliam, 1998; Wiliam et al., 2004) as a second protective factor in our work.

Thirdly, our success in helping many of our graduates enter the profession well versed in a SFA philosophy of assessment encourages us to persist with our approach. Because of completing our courses, some preservice teachers do come to understand assessment as formatively integral to student learning and success. Contact with these teachers once they have entered the profession confirms that many contemporary assessment and evaluation practices, supported by school board policy, are evident in the K-12 school system. Ongoing discussions with teachers enrolled in graduate courses indicate that many of our Bachelor of Education graduates are well-prepared to bring leadership to the schools in the area of classroom assessment and evaluation. This evidence of success adds to our determination and enables us to continue to collaboratively and explicitly model contemporary assessment practices.

\section{Concluding Thoughts}

Our self-study systematically examined the responses of our preservice teachers as we purposefully introduced competing assessment philosophies early in our courses and as we guided our preservice teachers' to inquire deeply into their assessment histories through a range of classroom activities and assignments. We have offered in this paper some of our recurring experiences in the assessment education of preservice teachers "so that more can be learned by future practitioners and...by future teachers and teacher educators” (Hamilton \& Pinnegar, 2013, p. 75). The experiential context of teacher educators encountering resistance and challenges in their teaching has not served as a well-established focus of research. In reflecting on this point, we have determined that 
rather than diminish the relevance of exploring this further, this lack of research has heightened the need for investigation. MacMillan \& Schumacher (1997) reiterate this need: "Exploratory studies which examine a topic in which there has been little previous research, are designed to lead to further inquiry" (p. 395). Hence, we suggest our work can serve as an impetus for further research in better understanding the assessment education of preservice teachers. 


\section{References}

Alberta Assessment Consortium. (2012). AAC Key Visual: Assessing student learning in the classroom. Retrieved from http://www.aac.ab.ca/

Beltman, S., Mansfield, C., \& Price, A. (2011). Thriving not just surviving: A review of research on teacher resilience. Educational Research Review, 6(3),185-207. doi.10.1016/j.edurev.2011.09.001

Black, P., \& Wiliam, D. (1998). Inside the black box: Raising standards through classroom assessment. Phi Delta Kappan, 80(2), 1-20. doi:10.1177/003172171009200119

Bullough, R.V., \& Pinnegar. S. (2001). Guidelines for quality in autobiographical forms of self-study research. Educational Researcher, 30(3), 13-21. doi:10.3102/0013189X030003013

Campbell, C., \& Evans, J.A. (2000). Investigation of preservice teachers' classroom assessment practices during student teaching. The Journal of Educational Research, 93(6), 350-355. doi:10.1080/00220670009598729

Chappuis, J. (2009). Seven strategies of assessment for learning $\left(1^{\text {st }}\right.$ ed.). Toronto, ON: Pearson.

Davies, A. (2004). Clapping exercise. In A. Davies (Ed.), Facilitator's guide to classroom assessment K-12, Conversation B1 - Foundational ideas: Why involve students in assessment? Courtenay, BC: Connections Publishing

Duncan, R.C., \& Noonan, B. (2007). Factors affecting teachers' grading and assessment practices. The Alberta Journal of Educational Research, 53(1), 1-21. Retrieved from http://www.ajer.ca

Earl, L. (2013). Assessment as learning: Using classroom assessment to maximize student learning ( $2^{\text {nd }}$ ed.). Thousand Oaks, CA: Corwin.

Erickcan, K., \& Barclay-McKeown, S. (2007). Design and development issues in provincial large-scale assessments: Designing assessments to inform policy and practice. The Canadian Journal of Program Evaluation, 22(3), 53-71. Retrieved from http://cjpe.journalhosting.ucalgary.ca/cjpe/index.php/cjpe/index

Goc Karp, G., \& Woods, M.L. (2008). Preservice teachers’ perceptions about assessment and its implementation. Journal of Teaching in Physical Education, 27(3), 327-334. Retrieved from http://journals.humankinetics.com/jtpe

Graham, P. (2005). Classroom-based assessment: Changing knowledge and practice through preservice teacher education. Teaching and Teacher Education, 21(6), 607621. doi:10.1016/j.tate.2005.05.001

Gu, Q., \& Day, C. (2007). Teachers' resilience. A necessary condition for effectiveness. Teaching and Teacher Education, 23(8), 1302-1316.

doi:10.1016/j.tate.2006.06.006 
Gunn, T.M., \& Hollingsworth, M. (2013). The implementation and assessment of a shared $21^{\text {st }}$ Century learning vision: A district-based approach. Journal of Research on Technology in Education, 45(3), 201-228. Retrieved from http://www.iste.org/learn/publications/journals/jrte

Hamilton, M.L., \& Pinnegar, S. (2013). A topography of collaboration: Methodology, identity and community in self-study of practice research. Studying Teacher Education, 9(1), 74-89. doi:10.1080/17425964.2013.771572

Kids and Learning First: A Plan to Help Every Student Succeed. (2012). Halifax, NS: Province of Nova Scotia.

Klinger, D., Deluca, C., Miller, T. (2008). The evolving culture of large-scale assessments in Canadian education. Canadian Journal of Educational Administration and Policy, (76). Retrieved from https://www.umanitoba.ca/publications/cjeap/

Klinger, D.A., Volante, L., \& DeLuca. C. (2012). Building teacher capacity within the evolving assessment culture in Canadian education. Policy Futures in Education, 10(4), 447-460. doi: 10.2304/pfie.2012.10.4.447

Koedel, C. (2011)._Education school grades and selection into teaching. Teachers College Record. Retrieved from http://www.tcrecord.org/

Lortie, D.C. (2002). Schoolteacher: A sociological study (2nd ed.). Chicago, IL: University of Chicago Press.

Loughran, J. (2006). A response to 'Reflecting on the self.' Reflective Practice: International and Multidisciplinary Perspectives, 7(1), 43-53. doi:10.1080/14623940500489716

Lunnenberg, M., Korthagen, F., \& Swennen, A. (2007). The teacher educator as a role model. Teaching and Teacher Education, 23(5), 586-601. doi:10.1016/j.tate.2006.11.001

Manitoba Education, Citizenship \& Youth. (2006). Rethinking classroom assessment with purpose in mind: Assessment for learning, assessment as learning, and assessment of learning. Retrieved from http://www.edu.gov.mb.ca/k12/assess/wncp/

McMillan, J.H., Hellsten, L.M., \& Klinger, D.A. (2011). Classroom Assessment: Principles and Practices for Effective Standards-Based Instruction. $1^{\text {st }}$ Canadian edition. Toronto, ONT: Pearson Canada.

Mitton-Kukner, J., Munroe, E., \& Graham, D. (in press). The challenge of differing perspectives surrounding grades in the assessment education of pre service teachers. The Canadian Journal of Higher Education.

Munroe, E., Foran, A., Graham, D., Curry, A., Lunney-Borden, L, MacLeod, K. (2012).Walking our talk about assessment with preservice teachers. in education, 18(2), 53-66. 
Popham, W.J. (2009). Assessment literacy for teachers: faddish or fundamental? Theory Into Practice, 48(1), 4-11. doi: 10.1080/00405840802577536

Popham, W.J. (2011). Transformative assessment in action: An inside look at applying the process. Alexandria, VA: ASCD.

Poth, C. (2013). What assessment knowledge and skills do initial teacher education programs address? A Western Canadian perspective. Alberta Journal of Educational Research, 58(4), 634-656. Retrieved from http://www.ajer.ca

Rojstaczer, S., \& Healy, C. (2010). Grading in American Colleges and Universities. Teachers College Record. Retrieved from http://www.tcrecord.org/

Roscoe, K. (2013). Enhancing assessment in teacher education courses. The Canadian Journal for the Scholarship of Teaching and Learning, 4(1), 1-15. DOI: http://dx.doi.org/10.5206/cjsotl-rcacea.2013.1.5

Schwab, J. (1983). The practical 4: Something for curriculum professors to do. Curriculum Inquiry, 13(3), 239-265. doi:10.1080/03626784.1983.11075885

Shepard, L., Hammerness, K., Darling-Hammond, L., Rust, F., Baratz Snowden, J., Gordon, E., et al. (2005). Assessment. In L. Darling-Hammond \& J. Bransford (Eds.), Preparing teachers for a changing world: What teachers should learn and be able to do. San Francisco, CA: Jossey-Bass.

Smith, K. (2011). Professional development of teachers-A prerequisite for AfL to be successfully implemented in the classroom. Studies in Educational Evaluation, 37, 55-61. doi:10.1016/j.stueduc.2011.03.005

Stiggins, R. (1999). Evaluating classroom assessment training in teacher education programs. Educational Measurement: Issues and Practice, Spring, 23-27. doi: 10.1111/j.1745-3992.1999.tb00004.x

Stiggins, R. (2002). Assessment crisis: The absence of assessment for learning. Phi Delta Kappan, 83(10), 758-765. doi: 10.1177/003172170208301010

Stiggins, R. (2005). From formative assessment to assessment for learning: A path to success in standards-based schools. The Phi Delta Kappan, 87(4), 324-328. doi:10.1177/003172170508700414

Stiggins, R. (2007). New mission, new beliefs: Assessment for learning. A DVD presentation. Portland, OR: Educational Testing Service.

Volante, L. (2006a). An alternative vision for large-scale assessment in Canada. Journal of Teaching and Learning, 4(1), 1-14. Retrieved from http://ojs.uwindsor.ca/ojs/leddy/index.php/JTL/

Volante, L. (2006b). Essential elements in teacher education: Preservice student perspectives. Alberta Journal of Educational Research, 52(2), 167-180. Retrieved from http://www.ajer.ca 
Volante, L. (2010). Assessment of, for, and as learning within schools: Implications for transforming classroom practice. Action in Teacher Education, 31(4), 66-75. doi: 10.1080/01626620.2010.10463536

Volante, L., \& Beckett, D. (2011). Formative assessment and the contemporary classroom: Synergies and tensions between research and practice. Canadian Journal of Education, 34(2), 239-255. Retrieved from http://www.cssescee.ca/CJE/

Volante, L., \& Fazio, X. (2007). Exploring teacher candidates’ assessment literacy: Implications for teacher education reform and professional development. Canadian Journal of Education 30(3), 749-770. Retrieved from http://www.csse-scee.ca/CJE/

Wang, J., Kao, H., \& Lin, S. (2010). Preservice teachers’ initial conceptions about assessment of science learning: The coherence with their views of learning science. Teaching and Teacher Education, 26(3), 522-529. doi: 10.1016/j.tate.2009.06.014

Wiliam, D., Lee, C., Harrision, C., \& Black, P. (2004). Teachers developing assessment for learning: Impact on student achievement. Assessment in Education: Principles, Policy, and Practice, 11(1), 49-65. doi: 10.1080/0969594042000208994

Wilson, N.S. (2008). Teachers expanding pedagogical content knowledge: Learning about formative assessment together. Journal of In-Service Education, 34(3), 283298. doi:10.1080/13674580802003540

Zeichner, K. (1995). Reflections of a teacher educator working for social change. In T. Russell \& F. Korthagen (Eds.), Teachers who teach teachers (pp. 11-24). London, UK: Falmer Press.

\section{Endnotes}

${ }^{1}$ Permission was obtained from students to share excerpts of their work.

${ }^{2}$ We refer to university students in our Bachelor of Education program as preservice teachers.

${ }^{3}$ Stiggins (2005) argues that assessment may be used to help students achieve learning success (Success for All) and describes the notion of "sort and rank" as representing a traditional understanding of assessment fostered by fixed grades where students are spread along an “achievement continuum” (p. 324) representing their rank upon graduation. 